\title{
Determinants of Choice of Management Control System in Cameroonian SMEs: A Contingency Approach
}

\author{
François-Xavier Mayegle $^{1}$ \& Solange Ngo Nguidjol ${ }^{2}$ \\ ${ }^{1}$ Department of accounting and Finance FEM, The University of Ngaoundéré, Ngaoundéré, Cameroon \\ ${ }^{2}$ Ph.D student, Faculty of Economics and Management, The University of Ngaoundéré, Ngaoundéré, Cameroon \\ Correspondence: Professor François-Xavier Mayegle, Department of accounting and Finance FEM, The University \\ of Ngaoundéré, Ngaoundéré, Cameroon. \\ Received: March 7, 2017 \\ Accepted: April 26, 2017 \\ Online Published: May 15, 2017 \\ doi:10.5430/jms.v8n2p25 \\ URL: https://doi.org/10.5430/jms.v8n2p25
}

\begin{abstract}
This is, from a survey of 232 Cameroonian SMEs, to understand and highlight the levers that SME managers rely to choose their business management control system. The successful theoretical framework is the contingency theory. It allows to highlight a number of factors explaining the choice of the management control system in SMEs: the perceived uncertainty of the environment, strategic positioning and leadership style of the CEO; and give a sense of the impact of each factor on the different operating modes of the management control system.
\end{abstract}

Keywords: management control system, contingency theory, SMEs

\section{Introduction}

The opening up of the Cameroonian economy to the world is marked by the increasing complexity of the environment in which all businesses, especially Small and Medium Enterprises (SMEs), operate. To mitigate these phenomena, SMEs have to adapt their structures and their modes of operation, by having a real management control system (MCS). This ability is the best guarantee of their survival and their competitiveness (Nobre, 2001b; Moalla, 2007; Mayéglè, 2007; Condor et Rebut, 2008; Bampoky et Meyssonnier, 2012).

Although the management control practices of large companies are the subject of continuous studies, the SME, unfortunately, remained outside the field of investigations of researchers specialized in the management control. However, the nature, the scale and specificity of the risk to which the structures are daily confronted would justify the development of a particularly refined MCS.

Studies in developed countries have provided a fairly complete knowledge of the methods and tools of management control implemented in Western SMEs (Meyssonnier et Zawadzki, 2007; Davila, 2005; Van Caillie, 2002; Lavigne, 2002; Nobre, 2001b). On the other hand, research in developing countries is less abundant. If scientific work is beginning to emerge on the instrumentation of management control in the emerging countries of Asia, Latin America and the Maghreb, there is still less for the countries of black Africa south of the Sahara.

Our study is expected to contribute to the debate on SME management control practices in developing countries, particularly in this country without a financial market that is Cameroon. For this reason, it seems appropriate to carry out a study on the explanatory or determinant factors that influence the choice of a MCS in Cameroonian SMEs.

This research, conducted empirically, begins with a descriptive study of the characteristics of the MCSs of SMEs. Due to their heterogeneous nature, there is an exploration of the potential determinants of the choice of management control systems within them.

This explanatory dimension of the study aims to partially validate the conceptual framework of Burns and Stalker (1961), Thompson (1967), Woodward (1965), Lawrence and Lorsch (1969), as presented by Beaulier and Salery (2006) Zampiccoli (2009), Perray-Redslob and Malaurent (2015), through the implementation of management control in the territorial collectivities and public bodies that have demonstrated the ability of this practice to adapt to organizations, whatever their complexity. This also tests the construct of the theoretical field marked out in these organizations. 
This article is built around three parts. It begins with a synthesis of the literature (1), followed by the methodology used to test the facts (2) and ends with the presentation and the discussion of the results (3).

\section{Management Control System and Contingency Factors: State of the Art}

The widespread idea in SMEs that the "management control" function is only useful to large firms (Van Caillie, 2003), proves to be a mistake. Fortunately, many SMEs do management control without knowing or naming it (Mayéglè, 2009, Meyssonnier and Zawadzki, 2007, Abi Azar, 2006, Nobre, 2001a). But do they always choose the one that suits them, in the light of what management control has been created and taught in the context of large organizations? In any case, it seems understandable that SMEs do not find what they need by simply copying the implementations of large structures.

Accordingly, since the beginning of the 21st century, research on management control in SMEs has become increasingly interesting (Bampoky and Meyssonnier, 2012, Kaboré, 2010, Sandino, 2007; Mayéglè and Ngo Nguidjol, 2005), because in a tense economic environment, it seems logical that researchers care about how these companies control their costs, develop their forecasts or objectives and monitor their realization. The MCS in the context of SMEs is a composition of procedures and tools generally included in the general information system of the organization and most often used informally by a company executive who is both the designer, The facilitator and the analyst (Van Caillie, 2003). As for its purposes, they are mainly influenced by the organization of the function, the actors of the control, the missions assigned to the management control, the frequency and the control tools used.

These leads to a brief presentation of the characteristics of the MCS of SMEs (1.1), and an exploration of the determinants of management control

\subsection{Description of Criteria Characterizing the MCS of SMEs}

Management control is increasingly seen as a device embedded in several aspects of organizational life (strategy, information systems, resource allocation, personnel management, organizational structure, organizational culture, organizational environment). This refers to the idea developed by Bouquin (2008) which states that management control in a broad perspective is an integral part of the management in the broad sense of the organization of which it is indissociable. Thus, management control can be characterized as a set of formal and informal artifacts and processes designed to influence the behavior of members of a structure and produce information about organizational processes and performance. From this definition, two common features emerge between all the forms of management control: the official control objective and the fact that they always refer to a performance evaluation. To mark this protean, it is better to speak of "management control systems", because a system refers to objects, practices and standards that, taken together, make sense.

The study by Santin and Van Caillie (2008) is one of the few, if not the only ones, that has attempted to give a general indication of the criteria characterizing the MCS of SMEs defined in relation to its exercise, its frequency and its tools. Thus, depending on the way in which management control is exercised, Dreveton (2011) and Whitley (1999) have pointed out that some companies have a centralized MCS with a top-down control approach, Autonomy is left to the staff. According to these authors, this type of management control system is more informal. Conversely, MCS can be decentralized (Dreveton and Rocher, 2010); In this case, the deployment of the control activity brings to light other roles within the management control (the budget controller, the departmental management controller, the management controller of a management, the controller Management of an activity center or a subsidiary). The head of the unit has a certain "autonomy" at each operational level, even if the activity is linked to the decision center and depends on the formalization that - sometimes - is imposed on it, to limit the distances (cultural, Economic, geographical, etc.).

The frequency of management control refers to the formalization of the MCS. This is one of the criteria that has been analyzed by multiple authors (Koblence et al., 2012, Langfield-Smith, 1997, Morales and Sponem, 2009). According to Simons (1995), formal SCGs, in a traditional view and in their mechanistic form, involve formal rules, standardized procedures, routines and regulations. Nevertheless, they can also be used interactively, in a non-traditional way, and support both organizational learning and environmental adequacy. While Langfield-Smith (1997) includes rules, standard operating procedures and budgeting systems, Bouquin (2008) points out that formal MCS is more visible, more objective, and easier to identify for research. It incorporates results controls that have a "feed-back" nature and stresses that they are often financial. According to Kabwigiri (2007), an informal MCS implies a model of reciprocal influence through a communication system between the two organizational levels. Bouquin (2008) notes that these are non-clairvoyant controls, unwritten policies that are often derived from, or an 
artefact of, organizational culture. This is why Bouquin, 2008; Coblence et al. 2012 argue that a MCS is a complementary set of tools, including both formal and informal controls. Moreover, the formalization of management control may be dependent on the nature of the informal controls set up.

The instrumentation of management control is the dimension most studied by researchers (Abi Azar, 2006, Bampoky and Meyssonnier, 2012, Kaboré, 2010, Van Caillie, 2002). To build a MCS, it is necessary to use different information tools that can guide the action. These tools are classified into two groups: traditional tools and contemporary tools. The traditionaltools represented by accounting, budget system, planning, dashboard, reporting, zero-based budget, have a strong financial connotation. They do not allow managers to control their management to achieve the organization's objectives because they are only financial, introverted and retrospective (Mayéglè, 2009, De Rongé and Cerrada, 2005). To be effective, the MCSmust always escape the comfort of stabilized patterns and organizations in order to retain its ability to question, alert and direct action. Unfortunately, only financial evaluation tools have proven to be incapable of providing a suitable framework for decision-making in companies. To address this issue, several answers are provided by management control theorists. These contributions, which are not mutually exclusive, are based on the assumption that some contemporary tools are extensions of classical techniques, while others are radically different and new.

Several tools adapted to informational competition have been set up. We can cite, among other things, total quality, management by activities or MBA target costing, benchmarking and the balanced scorecard that are considered the most prominent, are not mutually exclusive and may be complementary. This complementarity can be made necessary by the intrinsic limits of each system taken in isolation.

\subsection{The Theory of Contingency as an Explanatory Framework for the Choice of the SCGs of SMEs}

What determines the choice of a MCS in SMEs? Studies on this subject are still quite rare, as research on management control has focused on its practice and its implementation. It is for this reason that we first present the principles and postulates of the school of contingency to see how well it is adapted to the explanation of the diversity of the MCS (2.2.1). Subsequently, we will focus on the determinants used to explain the choice of MCS in SMEs (2.2.2).

\subsubsection{Explanation of the Choice of MCS by the Theory of Contingency}

With the school of contingency, universalist models are abandoned to approach relativistic models which aim rather to describe the functioning of organizations taking into account the diversity of situations.

Contingency theories have detected structural characteristics of organizations, internal factors of contingency, such as size, age, technology, or external characteristics such as the environment of organizations (Marginson, 2002). These contingency factors have evolutive characteristics that influence decisions and actors in the company.

Applied to control systems, the contingent approach leads to the study of MCS by assuming that actors act with the objective of adapting their MCS to changes in contingency factors to improve performance. This approach is found in Anthony (1988), which introduces a major innovation in relation to his evocations of 1965: the explanation of variations in management control practices based on contingency factors. He asserts that a number of factors are "likely to modify these typical practices" (Note 1): the external environment, internal factors (strategy, interdependence, management style ...) and factors specific to the industry.

Contingency theory is therefore a major theoretical framework: it is commonly used for the study of control systems (Colvaleski et al., 1996) and more widely for control methods (Chiapello, 1996). Consequently, its use in explaining the choice of the MCS seems appropriate.

\subsubsection{Factors Influencing the Choice of MCS}

The literature identifies size as one of the most studied factors in management control (Nobre, 2001a, Van Caillie, 2002, Abi Azar, 2006, Mayéglè, 2007, Kaboré, 2010). The next paragraph focuses on factors that are not well studied. It is a question of developing the major contextual elements that influence the implementation of a MCS, namely: perceived environmental uncertainty (PEU) strategic positioning and leadership style.

Among the first research in management control using the notion of PEU is that of Ferris (1982). The author discovers in a longitudinal study that the adaptation of the control system to the perceived uncertainty of the environment has a positive influence on the performance of employees in accounting firms. Gordon and Narayanan (1984), for their part, show that the organizational structure and characteristics of the internal information system depend on the perceived uncertainty of the environment. Later Fisher (1998), which draws on the work of previous authors, studies the influence of perceived environmental uncertainty on the information needs of managers. Thus, 
she nuances their studies by showing that these needs are different according to the personality of the manager, expressed in the variable Locus of external control (Note 2).

In the Western world, research has shown that the use of traditional tools in turbulent environments is not the same as in more stable environments (Berland, 2000; Gervais and Thenet, 1998). In addition, Touchais (2001) notes that The term "environmental turbulence" frequently used in French literature, although not covering the notion of uncertainty, is a factor that can contribute to the resentment of uncertainty in the environment perceived by managers and other members Organization. It seems then possible to opt for the use of the general concept of uncertainty, the environment may include different dimensions such as competitive intensity, turbulence, complexity etc.

Several characteristics of the environment have been studied by contingency theory: variability and turbulence, intensity of competition, technological changes or the recent nature of technology, complexity and uncertainty as a concept general. Among all these concepts, that of the uncertainty of the environment and particularly the uncertainty perceived by the managers seems to be the one that represents at best the factor of general and multidimensional contingency, leading to the implementation of the formalized MCS, Articulating by the results. Current research clearly indicates this contingency of management control over uncertainty in the environment.

In conclusion, uncertainty appears to be a highly explanatory variable of control systems (Hartmann, 2000). This concept leads to the modeling implemented in this research through the Sponem (2004) definition whereby "uncertainty is a change in the environmental conditions that affects the controlled process and makes predictions difficult and the setting of a" Objections ".

Theoretically, contingency predicts that in times of turbulence, conventional planning tools such as the budget are abandoned to the profile of contemporary tools such as the balanced scorecard (Koblence et al., 2012).

The external environment is also a central contextual variable in contingent research (Donaldson, 1996). However, there are various ways of approaching the environment. For Hartmann (2000), uncertainty is usually seen as affecting the controllability, completeness and relevance of the budgetary evaluation. It makes it difficult, in fact, to judge ex-post the good or bad performance measured in budgetary terms. From a theoretical point of view, this author deduces that, in a situation of uncertainty, budgetary evaluation is frequent.

According to contingent theory, when an external environment becomes more uncertain, the structure responds by increasing differentiation, which in turn requires an increase in the use of integrating mechanisms, such as budgetary participation to coordinate actions (Shields and Shields, 1998). Yet at the empirical level Ezzamel (1990) finds that management control is more important in a situation of uncertainty, while Wright and Stigliani (2012) show that it has a beneficial effect on performance in this context. These observations make it possible to pose the first hypothesis which holds that "the perceived uncertainty of the environment pushes for the formalization of the management control system in SMEs in Cameroon".

The strategy of organizational entities is also a major factor of internal contingency proposed in the literature and the one that interests our problem. Since Child (1972) admitted the notion of strategic choice, the appropriateness of the structure and the mode of control of the company to the contextual factors necessarily passes by the concordance to the political choices of the decision-makers of the company. More than a decade after research on the influence of the type of organizational strategy on the most effective and efficient techniques and modes of control, Langfield-Smith (1997) proposes a comprehensive state of the art. The author concludes that although some relationships are detected in The level of theorization of these relations remains weak because of the sometimes contradictory empirical results. This is the case for the correspondence between the type of strategy and the mode of control in place to achieve this strategy. However, it does offer some interesting avenues for future research, focusing on the importance of the different tools and types of performance measures, depending on the type of strategy put in place. A few years later Chenhall (2003) presents a synthesis of contingency factors studied in the literature, including the type of strategy. It also recognizes that the adequacy between the different types of strategy and the different modes of control is not clearly established.

Santin and Van Caillie (2008) study the influence of various contingency factors, including the strategy on the design of the management control system. On the basis of five dimensions to describe the design of the control system, they show that firms with a strategy of cost dominance generally have more bureaucratic control systems (controls by actions, formal, precise, restrictive and impersonal) That companies whose strategy is the differentiation of products. It is indeed a way of considering the influence of the strategy on the mode of adequate management control. Another wave of research focuses on the relationship between types of strategy and the use of strategic management control or non-financial tools for measuring and controlling performance (Mayéglè, 2009). The results of this research can 
contribute more to the explanation of the relationship between the type of strategy and the relative importance of modern control tools compared to traditional tools. According to Komarev (2007), the precursor of this current is undoubtedly Shank (1989). The latter proposes at the end of the 1980 a theoretical reflection on the importance of the control tools according to the chosen strategic positioning. However, the accounting and financial tools, whether they are old or coming from the new management control, would be decisive in the control system only in the case of a strategy of cost dominance. This conclusion is very important because it proposes that only non-financial or mixed scorecards such as the Balanced Scorecard can be of particular use for the implementation of differentiation strategy. Other recent tools of a rather accounting nature such as strategic cost analysis or Rolling Forecasts remain in excellent alignment with low cost strategy. The type of competitive strategy would therefore be a contingency factor to separate the traditional tools from the new ones in the search for the adequacy between the MCS and the elements of the internal context.

The contingency model proposed by Jermias and Gani (2004) suggests that, in order for the differentiation strategy to contribute to better organizational performance, it should be accompanied by a decentralized structure, behavioral type controls and an organized information system Around new tools and new performance measures (monitoring of quality and customer satisfaction, benchmarking, long-term orientation etc.). Conversely, the low-cost strategy can only be efficient if it is accompanied by a centralized organizational structure, a mode of control by results and a highly accountable management information system (budgets, cost analysis Including activities etc.). The originality of this study lies mainly in the test method used inspired by research in biology (Note 3): The two authors show As well as, for both types of strategy, compliance with the contingent adaptations between strategy, organizational structure and type of management control information system leads to better performance. On the other hand, the hypothesis on the mode of control has not been verified. Companies with a differentiation strategy do not use personal controls more than firms with cost-dominance strategy. A more in-depth analysis shows that firms with differentiating strategy use both modes of control in a very sustained manner. This conclusion seems to be very important at this stage because it produces one more argument in the general impression expressed so far. This implies that the different types of strategy lead to the need for different management control systems and the use of different control tools: rather they are accountable for low cost and less accounting strategy for differentiation. The above considerations legitimize the formulation of the second hypothesis of this research, namely that "The strategic positioning of the SME influences the choice of the management control system. "

On the other hand, Chapellier (1994), Sponem (2004) and Christol et al (2011) demonstrate in their work that the management control system of firms is very dependent on the individual who uses it. This is why the pure contingent approach needs to be expanded by integrating the behavioral analysis of the leadership style of the leader.

The notion of leadership has had multiple and diverse definitions, but most of them share the assumption that it implies a process of influence, aimed at facilitating the performance of a collective task (Yukl et al., 2002). The definition of Jacquet (2013) is the one that we will retain because it seems the most complete. It defines leadership as "the art of bringing people to do tasks voluntarily, which gives them the motivation to dedicate their efforts to the achievement of common goals." Leadership is no longer given to a person; It is the culmination of a dynamic that reigns within the members of a group.

In the management control literature, the variable Leadership style was mentioned for the first time in the research of the current RAPM (Komarev, (Note 4) 2007), and this from the birth of the current. The aim was then to link the general leadership style of the leader to the way he used the budget tool. Several studies of the current contingency also show the primordial role of the manager or the leader in the situations of uncertainty of the environment. Some of them have already been studied in terms of the link between the leadership style and the characteristics of the control system, with the uncertainty of the environment as a moderator of this link (Benabdeljlil, 2007). Other research is specifically dedicated to the management style in an uncertain or turbulent environment. Thus, Alcouffe et al. (2003) are interested in the most effective management style in turbulent environments. The authors suggest four characteristics of the efficient management style when the environment changes rapidly: the constant focus of attention on consumer demands, constant encouragement of innovation, empowerment, The affinity for change. To date, it has been shown that the leadership style can be used to define situations where the MCS should be organized around modern tools and formal controls, rather than around personal and less formal controls.

It is necessary at this stage of the analysis to question the link that may exist between the leadership or management styles envisaged above and the notions of ideology or doctrine of the management which we plan to integrate into the Choice of the management control system. Indeed, this link is quite intuitive: the leadership style characterized by a 
strong degree of structure generation and task focus is very conservative in nature and associated rather with an old vision of management. (Note 5)

More than cognitive approaches to management, leadership styles can be interpreted as external signs of managers' adherence to one of these two management doctrines or ideologies. It may be necessary to distinguish a third style that allows integration not of adherence to the behaviourist doctrine or of human relations but of adherence to the ideas of organizational learning, innovation and perpetual change (Yukl Et al., 2002). In particular, this change-oriented leadership style would convey the leader's adherence to the new management control school and should explain the periods and frequency of management control. These various developments make it possible to formulate the third hypothesis of this research, which would require that "the style of leadership conditions the mode of operation of management control" and leads to the presentation of the method of research used to test the facts.

\section{Methodology of Research}

The state of knowledge, the stated objectives and the research question have oriented this research towards a quantitative methodology. To test the hypotheses formulated, an empirical study was carried out with a sample of SMEs based in Cameroon.

\subsection{The Collection of Data}

Field data were collected through a questionnaire. This was developed and administered face-to-face with 250 SMEs. The sampling unit is represented by any person who has the title of owner-manager, or an employee officer. The choice of these people as the contact person has been validated by many authors (Ben Hamadi and Chapellier, 2013), that the latter has a significant influence on the management control methods of the SME and, Measure how the devices that support them are developed and used.

The questionnaire consisted of 5 parts. The first was to collect information on the characteristics of the external environment of the SME. The second included questions on the type of strategy. The third was to collect information on the leader's leadership style. The fourth included questions relating to the characteristics of the management control system. The fifth, was intended to gather general information about the company. Questions were asked in the form of "yes" or "no" questions, multiple choice questions and Lickert scales. 243 questionnaires were returned (response rate 97.2\%). 232 of them proved to be exploitable.

Data processing was performed using SPSS 20 software. This allowed us to use flat sorts to describe the sample and, correlations and regressions to test assumptions after purification of the measurement scales of Variables (see appendix2).

\subsection{Characteristics of the Sample}

To complete our study, 232 SMEs were selected. The result is a sample with the following characteristics: commercial SMEs are the most represented (39.7\%). SMEs in services (28.4\%), industrial SMEs (26.3\%), and artisanal SMEs (5.6\%) followed by representativeness.

Using the size criterion, measured by the number of employees, firms with a size between 10 and 49 employees account for more than half of the sample (i.e. 52.6\%), symbolizing small firms. Those with a workforce of between 50 and 100 employees are 47.4\%; These are medium-sized companies. These two categories represent the SME of Cameroon (according to Law No. 2010/001 of 13 April 2010 of the Presidency of the Republic of Cameroon). In addition, the sample consists of $46.1 \%$ of individual enterprises; Of 36.6\% SARL and 14.2\% SA. In addition, there are other legal forms of SMEs, grouped in "Others" and representing 3\%. These are 4 NGOs, and 3 CIGs.

Respondents are owner-managers $(33.6 \%)$ or salaried managers $(66.4 \%)$. This contrasts with the current literature that SME managers are generally owners (Torres, 2008). This situation is most likely due to the fact that the economic crisis has led company managers and civil servants to invest in the creation of SMEs. Since they cannot abandon their jobs and devote themselves exclusively to their structures, they are called upon to employ the salaried managers to deal with them, at least for the operational aspects of management. It is also noted that the survey covered all the chiefs of the ten regions of Cameroon.

\section{Results and Discussion}

\subsection{Management Control Procedures in SMEs}

Appendix 1 highlights the characteristics of MCS in the sample's SMEs. Thus, according to the formalization of the SCG, the results show that $83.6 \%$ of SMEs in the sample have a formal management control system. These results coincide with the work of Mayéglè (2007), which stipulates that SMEs have integrated and understood the need for a 
management control system. Although $16.4 \%$ of SMEs answered in the negative, this does not imply that they do not carry out management control. Indeed, according to the work of Abi Azar (2006), the lack of formalization of management control in an SME does not imply its non-existence, since it is often associated with other functions. As far as management control is concerned, it is as much centralized (49.1\%) as decentralized (50.9\%) in the SMEs in our sample, although decentralization is somewhat higher than centralization. This corroborates the work of Perrow (1970), for whom decentralization often involves some formalization of management controls. This conclusion is consistent with most of the results obtained in the literature (Lavigne, 2002, Meyssonnier and Zawadzki, 2007, Nobre, 2001a, Van Caillie, 2002).

As for the instrumentation of management control, we have been cautious in taking into account statements about the existence of certain tools. In order to do this, we carried out a PCA because, it seemed to us after factorization, that sometimes the answers overwhelmed the reality on the ground (this is the case of declared use of the scoreboard, benchmarking, The ABC / ABM method, target costing). Indeed, in this type of questionnaire survey, the respondent may inadvertently declare having a tool. The respondent may even be mistaken - in good faith - about the nature of the tool by giving it an inadequate name. He may feel that the tool exists because he knows it but is not available in the company. In addition, the tool may be available without being used. In the end, after the ACP, we obtained two sets of tools: traditional tools (general accounting, cost accounting, reporting, budget and planning); And contemporary tools (TBP). In sum, it is also noted that the actors of management control can be very different. Management control can be carried out by the management owner, the employee manager, the management controller, the internal accountant or the external accountant.

\subsection{The Incentives for the Choice of MCSin Cameroonian SMEs}

In order to control the construction of our variables to the extent that they are usually captured through traits and attributes, we verified the unidimensionality of each concept implemented through a factor analysis (ACP) in order to Components (see appendix2).

Correlation results and regression tests using data collected from the owner-managers and salaried managers of the 232 SMEs that constitute the research sample indicate that the variables representative of the characteristics of the MCS and the contingency factors (PEU, strategy and leadership style) agree. The hypotheses formulated have therefore all been validated statistically by regression tests (see Appendix 3).

4.2.1 Perceived Environmental Uncertainty and Formalization of the SME Management Control System of the Sample

The perceived uncertainty of the environment is measured by two variables, namely, the complexity and variability of the environment; The formalization of the management control system is represented by traditional tools and the formal management control system.

The simple or multiple linear regression tests have established a positive influence between the perceived uncertainty of the environment and the formalization of the management control system. The statistically significant link between the perceived complexity of the environment and the use of traditional management control tools is consistent with the results obtained by Anthony (1988), Hartmann (2000), Sponem (2002, 2004) and Komarev 2007).

Anthony (1988), the father of the discipline (Note 6), demonstrates the explanation of variations in management control practices based on contingency factors. He asserts that a number of factors are likely to change typical management control practices, as is the case with the external environment. He confirms this link by pointing out that in the event of uncertainty, companies can carry out revisions and / or "re-forecasting". For Hartmann (2000), uncertainty is usually seen as affecting the controllability, completeness and relevance of the fiscal assessment. Precisely, in our study the perceived complexity of the environment explains $61,873 \%$ (Note 7 ) of the variance of the use of traditional tools. Student's T values are 7.591 for quantitative complexity and 8.035 for qualitative complexity. By means of structural equations, Komarev (2007) shows that there is a positive link between the perceived complexity of the environment and the size of the fiscal framework, while insisting that this relationship remains uncorrelated across groups Companies. It should be noted that the budget is classified as a traditional tool. However, these results contrast with the findings of Gervais and Thenet (1998), Berland (2000), who predict that in times of turbulence, conventional planning tools are abandoned to the profile of contemporary tools (such as the dashboard Prospective). This could be explained by the strong financial connotation of traditional tools because they do not allow managers to master their management in order to achieve the objectives of the structure. Moreover, their use 
leads to a weakness in the flow of information. Only the SMEs in the sample use these tools because they are easily manipulated (accounting, budget, dashboard) and adapted to their small and medium size entity.

Similarly, there is a statistically significant relationship between perceived environmental variability and the provision of a formal management control system. These results follow the same logic as those of Ezzamel (1990). This author underlines that in a situation of environmental uncertainty, the explanation of the variance takes a greater interest because the risks are more important. It makes it difficult, in fact, to judge ex post the good or bad performance measured in budgetary terms. From the theoretical point of view, this author deduces that in a situation of turbulence, management control is frequent. Similarly, Komarev (2007) shows that although it is not very regular, there is also a positive relationship between the variability dimension of the environment and the variable frequency of the budget cycle. This frequency of the budgetary cycle or of the management control is perceived as the disposition of a formal management control system. Two factors in the environment therefore seem to explain the size of the budgetary arrangements of French companies. This study makes it possible to show that these factors are also structuring for the formalization of the management control system of Cameroonian SMEs. These conclusions attest to what the positive approach of contingency theory postulates. For example, Sponem (2004) notes that the level of explanation produced by contingent determinants is not negligible. To some extent, organizations adapt their budgeting process to their "technical environment". Like Colvaleski et al (1996), it is interesting to think that uncertainty is a change in the environmental condition that affects the structure, makes forecasts difficult and the setting of objectives troublesome.

The complexity dimension is linked to the difficulty for the leader to establish clear links of cause and effect between the events of the environment and their consequences for the organization. It may also be linked to a lack of information on the state of the constituent elements of the environment or the possibilities of reacting to the change of these elements. The variability dimension represents the speed and magnitude of changes in the elements of the environment. The variability of the environment requires a rapid response and anticipation on the part of the organizational leaders. These two dimensions of the perceived uncertainty of the environment therefore significantly favor the use of traditional tools and the formal configuration of the management control system of Cameroonian SMEs because the training (Note 8) received by the leaders of the said SMEs leads them to believe That they should control the reality by manipulating the financial variables.

\subsubsection{Strategic Positioning and Choice of the SME Management Control System of the Sample}

The linear regression tests have permitted to confirm the hypothesis that strategic positioning influences the choice of MCS. The latter is measured by decentralized management control and contemporary tools. Given that the strategy has proved to be a one-dimensional concept in our analyzes (ACP), it is particularly interesting in that it has not yet been used in previous research. Indeed, until the 1980s, the strategy was not explicitly used as a variable in control systems research (Langfield-Smith, 1997) (Note 9). At present, it is a contingency factor that is increasingly important in the explanation of management control systems (Bouquin, 2008, Langfield-Smith, 1997), and has always been a multidimensional variable.

The strategy is strongly correlated with the choice of MCS. We find a model that reduces to simple linear regression with a clearly satisfactory T-value of Student, since it rejects the null hypothesis at a very comfortable threshold of 0,000. Despite the one-dimensional quality of the strategy of this study, the results corroborate approximately the previous studies which affirm the influence of the strategy on the control systems. It is notably the studies by Govindarajan and Fisher (1990), Jermias and Gani (2004) who, in their conclusions, suggest a focus of decision makers' interest in contemporary management control tools. A very short delivery time strategy would therefore be directly associated with a greater relative importance of modern management control tools (Shank, 1989). It emerges from the author's reflection that the tools of a non-accounting and financial nature or emerging from the new management control current would be predominant in the MCS in the case of a delivery time strategy. This conclusion is very important because it suggests that only non-financial or mixed scorecards such as the Balanced Scorecard can have a specific utility for implementing differentiation strategy.

For Perera et al. (1997), a time differentiation strategy would be associated with a strong preference for non-accounting control tools such as balanced scorecards. Therefore, the smaller the SME focuses on the short delivery time strategy, the more it uses modern management control tools.

On the other hand, their studies (Gupta and Govindarajan, 1982; Shank, 1989) have shown that conservative orientation strategy, short delivery time strategy, defensive strategyor cost dominance are more effective when they are Supported by a centralized management control system, a highly formalized work based on rigorous control. This is contrary to our results, since the link between the strategy and the layout of a decentralized management control 
system is positive and significant $(\beta=0.495, \mathrm{p}<0.000)$. This result is similar to that of Sponem (2002). In fact, it distinguishes two types of strategythat must theoretically correspond to a specific model of management control. In practice, putting forward a single dimension "Strategy" may be particularly relevant in the choice of management control system. Leaders will no longer focus on a single strategy but will seek to mobilize several types of strategy to implement a management control system. For this, the use of contemporary tools is adequate because they allow a more strategic orientation of the SME; And the decentralization of the MCS is advocated because it allows staff to participate in the company's objectives.

\subsubsection{Leadership Style and Procedure for Management Control of SMEs in the Sample}

The findings of this research establish a positive and significant relationship between the leadership style and the operational control mode. The first test shows the impact of progressive leadership (oriented relationship or change) on the use of contemporary management control tools. Indeed, the two factors of the visionary leadership of change and development and confidence are significant $(0.418$ and $0.470, \mathrm{p}<0.000)$. These findings are consistent with the allegations of Komarev (2007), Sponem (2004), for whom the leadership style is expressed by the development of strong human relationships between management and subordinates. It may also be to stimulate group work, collegial decisions and delegation of responsibilities. The non-financial and strategic control tools are therefore put in place to replace the traditional tools very rigid. The dimensions of leadership also reflect management's adherence to innovative management doctrines and positively influence the use of modern management control tools. These results are similar to those of Yukl et al. (2002) find that the relative importance of progressive doctrines in the leadership style invariably leads to a proportional decrease in the proportion of budgets to scorecards and proportional scaling of the scale Of the budgetary system. This shows that the use of modern tools is linked to the progressive vision of leadership; In other words, it helps accelerate the replacement of traditional tools with other innovative management tools. Among other things, it is this change-oriented leadership style that would convey the SME leader's adherence to the new School of Strategic Management Control.

Similarly, our tests highlight the influence of the two dimensions of leadership on the establishment of a formal management control system. This conclusion is consistent with the work of Yukl et al., (2002). These authors emphasize that, leadership styles can be interpreted as external signs of the adherence of managers to a management doctrine or ideology. Our conclusions therefore encourage the adherence of Cameroonian SME managers to a progressive leadership style that should allow them to formalize the frequency of management control, in other words, have formal, structured, visible and objective management control.

\section{Conclusion}

This research has proposed to study the elements that influence the choice of the MCS in the SMEs of Cameroon with regard to the theory of the contingency. Based on a review of the literature, three hypotheses have been developed to study this link. The first was to consider that the perceived uncertainty of the environment could have an impact on the formalization of the SME management control system in the sample. The second was based on the idea that strategic positioning could influence the choice of the SME management control system. The third accepted that the leadership style could have an impact on the management mode of the SMEs in the sample. The results of the research carried out among 232 SMEs based in Cameroon show that the aforementioned determinants determine the implementation of the MCS.

The main scientific contribution of this study lies in the knowledge of management control choices and practices in developing countries and without a truly operational financial market such as Cameroon. The contribution for professionals lies in highlighting ways of improving instrumentation in Cameroon, especially in local SMEs. Thus, from the theoretical point of view of the design of the MCS, research tends to validate the existence of a positive relation between factors (structural of the entity and behavioral of the leader) and choice of the MCS.

At the managerial level, it suggests that it is necessary to combine the action of these three factors in understanding the complexity of the management control organization in the SME. It proposes to the managers to act on these three levers to develop the effectiveness of this device.

It should be noted, however, that there are limits to our study. Indeed, the strictly quantitative analysis restricts our field of study because, a qualitative approach would allow another representation and a better perception of the phenomena studied. All these observations lead us to propose some directions of extension for our research. First, the development of case studies or a qualitative approach to identify other explanatory factors for the choice of MCS appears to be a relevant perspective to complement the quantitative study. A comparative study between SCGs set up in Cameroonian SMEs and those of subsidiary SMEs of a foreign company would be interesting in that it would 
make it possible to better understand the adaptation of the MCS to the non-Cameroonian context and its determinants Which certainly have an influence on the management control system adopted.

\section{References}

Abi Azar, J. (2006). Les outils de contrôle de gestion dans le contexte des PME : cas de PMI au Liban. Congrès de l'Association Francophone de Comptabilité, Tunis, 22.

Alcouffe, S., Berland, N., \& Levant, Y. (2003). Les facteurs de diffusion des innovations managériales en comptabilité et contrôle de gestion: une étude comparative. Comptabilité-Contrôle - Audit. Numéro spécial, mai, 7-26.

Anthony, R.N. (1988). The Management Control Function. Harvard Business School Press, Boston.

Bampoky, B., \& Meyssonnier, F. (2012). L'instrumentation du contrôle de gestion dans les entreprises au Sénégal. Comptabilité et innovation, Mai, HAL, Grenoble, France, 27.

Beaulier, M., \& Salery, Y. (2006). Vingt ans de contrôle de gestion dans les collectivités locales : bilan et perspectives. Revue française de finances publiques, (95), septembre, 69-85.

Ben Hamadi, Z., \& Chapellier, P. (2013). Innovations budgétaires en PME et profil du dirigeant, Comptabilité sans frontière. The french connection, Canada, pp cd (rom, <hal-00996784>. Retrieved from https//hals.archives-ouverts.fr

Benabdeljlil, N. (2007). Les modes de management des entreprises au Maroc: entre contingences culturelles et économiques. Revue Internationale PME, 20(2), 89-122.

Berland, N. (2000). Fonctions du contrôle budgétaire et turbulence, Actes de conférence: XXI Congrès de l'Association Francophone de Comptabilité, 18-19-20 mai, Angers.

Bouquin, H. (2008). Quelles perspectives pour la recherche en contrôle de gestion? In Finance Contrôle Stratégie, juin, 11, 177-191.

Bruns, W.J. Jr., \& Waterhouse. J.H. (1975). Budgetary control and organizational structure/ Journal of Accounting Research, Automne, 177-203.

Burns, T., \& Stalker, G.M. (1961). The Management of Innovation. Tavistock, London.

Chapellier, P. (1994). Comptabilités et Système d'Information du Dirigeant de PME - Essai d'observation et d'interprétation des pratiques. Thèse de Sciences de Gestion - Université de Montpellier II.

Chenhall, R.H. (2003). Management control systems design within its organizational context: findings from contingency-based research and directions for the future. Accounting, Organizations and Society, 28(2/3), 127-168.

Chiapello. E. (1996). Les typologies des modes de contrôle et leurs facteurs de contingence: un essaie d'organisation de la littérature. Comptabilité, Contrôle, Audit, 2(2), septembre. 51-74.

Child. J. (1972). Organizational Structure, Environment and Performance: The Role of Strategic Choice. Sociology, 6(1), Jan., 1-22.

Christol, D., Laize, C., \& Radu Lefèbvre M. (2011). Leadership et Management, Ettre Leader, ça s'apprend. De Boeck

Coblence, E., Aubouin, N., \& Kletz, F. (2012). Les outils de gestion dans les organisations culturelles : de la critique artiste au management de la création. Management et Avenir, 54, 192-215.

Condor, R., \& Rebut, K. (2008). Déterminants et modes opératoires du contrôle de gestion dans les PME : une approche qualitative comparative. Comptabilité-Contrôle-Audit, 19.

Davila, T. (2005). An exploratory study on the emergence of management control systems: formalizing human resources in small growing firms. Accounting, Organizations and Society, 30, 223-248.

De Rongé, Y., \& Cerrada, K. (2005). Contrôle de gestion. Pearson Éducation, 262.

Donaldson, L. (1996). The normal science of structural contingency theory. In Clegg, S.R., Hardy, C., \& Nord, W.R. (Eds.), Handook of organizational theory, pp.57-76

Dreveton, B. (2011). Construire un outil de contrôle au sein des organisations publiques : une opportunité au développement d'un nouveau mode d'action. Management International, 15(4), 11-24.

Dreveton, B., \& Rocher, S. (2010). "Lost in translation", étude de la construction d'un outil de gestion dans une région française. Comptabilité-Contrôle-Audit, 16(1), 83-100. 
Ezzamel, M. (1990). The impact of environmental uncertainty, managerial autonomy and size on budget characteristics. Management Accounting Research, 1, 181-197.

Ferris, K.R. (1982). Perceived environmental uncertainty, organizational adaptation and employee performance: A longitudinal study in professional accounting firms. Accounting, Organizations and Society, 7(1), 13-25.

Fisher, J.G. (1998). Contingency Theory, Management Control Systems and Firm Outcomes: Past Results and Future Directions. Behavioral Research in Accounting, Supplement, 10, 47-64.

Gervais, M., \& Thénet, G. (1998). Planification, gestion budgétaire et turbulence. Finance, Contrôle, Stratégie, l(3), septembre, 57-84..

Gordon, L.A., \& Narayanan, V.K. (1984). Management accounting systems, perceived environmental uncertainty and organization structure: An empirical investigation. Accounting, Organizations and Society, 9(1), 33-47.

Govindarajan, V. (1986a). Impact of Participation in the Budgetary Process on Managerial Attitudes and Performance: Universalistic and Contingency Perspectives. Decision Sciences, 17(4), Fall, 496-516.

Govindarajan, V., \& Fisher, J. (1990). Strategy, control systems, and resource sharing: Effects on business-unit performance. Academy of Management Journal, 33(2), June, 259-285.

Gupta, A.K., \& Govindarajan, V. (1982). An Empirical Examination of Linkages Between Strategy, Managerial Characteristics, and Performance. Academy of Management Proceedings, 31-35.

Hartmann, F.G.H. (2000). The appropriateness of RAPM: toward the further development of theory. Accounting, Organizations and Society, 25(4-5), 451-482.

Jacquet, S. (2013). Le leadership: un état personnel, des capacités ou une réelle intelligence situationnelle? Présentation des grands courants d'explication du leadership CREG, décembre, 25.

Jermias, J., \& Gani, L. (2004). Integrating business strategy, organizational configurations and management accounting systems with business unit effectiveness: a fitness landscape approach. Management Accounting Research, 15, 179-200.

Kaboré, S. (2010). Systèmes d'animation du contrôle de gestion dans les entreprises burkinabé : étude transculturelle. Thèse de Doctorat, décembre, Rennes 1, 365.

Kabwigiri, C. (2007). Le design des systèmes de contrôle de gestion en contexte d'incertitude: une étude empirique du cas des spin-offs académiques de haute technologie. Thèse de Doctorat, HEC-École de Gestion de l'Université de Liège.

Komarev, I. (2007). La place des budgets dans le dispositif de contrôle de gestion: une approche contingente. Interpréter le passé pour modéliser le présent. Thèse de Doctorat en Sciences de Gestion, université Montesquieu - Bordeaux IV, 725.

Langfield-Smith. (1997). Management Control Systems and Strategy: A critical review. Accounting, Organizations and Society, 22(2), 207-232.

Lavigne, B. (2002). Contribution à l'étude de la genèse des systèmes d'information comptable des PME : une approche empirique, Actes du XXIIIème Congrès de l'Association Française de Comptabilité, Toulouse.

Lawrence, P.R., \& Lorsch, J.W. (1969). Organization and Environmen. Irwin, Homewood.

Lima, E. O. (2003). Stratégie de PME: de la perspective traditionnelle aux approches descriptives axées sur le processus, Cahier de recherche, avril, d'entrepreneurship Maclean Hunter: HEC Montréal.

Marginson, D. E. W. (2002). Management Control Systems and their Effects on Strategy Formation at Middle-Management Levels: Evidence from a U.K. Organization. Strategic Management Journal, 23, 1019-1031.

Mayéglè, F-X. (2007). Contrôle de Gestion et développement des petites et moyennes entreprises en Afrique: une application à partir du Tableau de Bord Prospectif in Création, Développement Gestion de la petite entreprise africaine. Edition clé. Février.

Mayéglè, F-X. (2009). La contribution du tableau de bord prospectif à l'amélioration des performances des entreprises: une étude à partir de 06 cas au Cameroun. Thèse de Doctorat d'État en Sciences de Gestion, université de Yaoundé II-Soa, 465.

Mayéglè, F-X., \& Ngo Nguidjol, S. (2005). L'exercice du contrôle de gestion en contexte sous-développé: le cas du Cameroun; Étude comparée des entreprises étrangères et des entreprises à capitaux nationaux, Actes du colloque de l'INSCAE, Antananarivo-Madagascar, 2, 3,4 Novembre. 
Meyssonnier, F., \& Zawadzki, C. (2007) L'introduction du contrôle de gestion en PME: étude d'un cas de structuration tardive de la gestion d'une entreprise familiale en forte croissance. Congrès de l'Association Francophone de Comptabilité, Poitiers, 17.

Moalla, H. (2007). Les mécanismes de diffusion, d'adoption et de rejet de la méthode ABC dans l'environnement tunisien. Actes du 28ème congrès de l'AFC, Poitiers, mai.

Morales, J., \& Sponem, S. (2009). Rationaliser, dominer, discipliner -Une revue des recherches critiques en contrôle de gestion. In Série K. (Ed.), Économies et Sociétés (Vol. 43, No. 12, pp. 2001-2043). Sciences de Gestion.

Nobre, T. (2001a). Le contrôleur de gestion en PME. Comptabilité-Contrôle-Audit, mars, 129-146.

Nobre, T. (2001b). Méthodes et outils du contrôle de gestion dans les PME. Finance-Contrôle-Stratégie, juin, 119-148.

Perera, S., Harrison, G., \& Poole, M. (1997). Customer-focused manufacturing strategy and the use of operations-based non-financial performance measures: A research note. Accounting, Organizations and Society, 22(6), 557-572.

Perray-Redslob, L., \& Malaurent, J. (2015). Traduction d'un outil de contrôle de gestion dans le secteur public. Le cas du BSC dans l'armée de terre française. Revue française de gestion, (250), mai, 49-64.

Perrow, C. (1970). Organizational analysis: a sociological view. Wadsworth Publishing Company, Californie, 270.

Sandino, T. (2007). Introducing the first management control systems: evidence from the retail sector. The Accounting Review, 82(1), 265-293.

Santin, S., \& Van Caillie, D. (2008). Le design du système de contrôle de gestion des pme: Une quête de stabilité adaptative. Cahier de Recherche, Working Paper, November 08 / N²00811/01.

Shank, J.K. (1989). Strategic cost management: new wine, or just new bottles? Management Accounting Reasearch, march, 47-65.

Shields, J.F., \& Shields, M.D. (1998). Antecedents of participative budgeting. Accounting, Organizations and Society, 23(1), 49-76.

Simons, R. (1995). Levers of Control: How Managers Use Innovative Control Systems to Drive Strategic Renewal. Harvard Business School Press, Boston, Massachusetts, USA.

Sponem, S. (2002). L'explication de la diversité des pratiques budgétaires: une approche contingente. Université Paris-Dauphine, 24.

Sponem, S. (2004). Diversité des pratiques budgétaires des entreprises françaises: proposition d'une typologie et analyse des déterminants. Thèse de doctorat, Paris-Dauphine, Paris, 482.

Thompson, J. (1967). Organizations in Action: Social Science Bases of Administrative Theory. McGraw-Hill, New York.

Torrès, O. (2008). Pour une approche contingente de la spécificité de la PME. Edition Economica, 19.

Touchais, L. (2001). Le contrôle de gestion en situation d'incertitude : le cas du sport spectacle. Finance Contrôle Stratégie, 4(1), mars, 215-237.

Van Caillie, D. (2002). Enquête sur les pratiques et les besoins en matière de contrôle de gestion dans les PME wallones. Cahier de recherche, Collection du département de gestion de l'Université de Liège.

Van Caillie, D. (2003). L'exercice du contrôle de gestion en contexte PME. Congrès annuel de l'Association Francophone de Comptabilité, Louvain-la-Neuve.

Whitley, R. (1999). Firms, institutions and management control: the comparative analysis of coordination and control systems. Accounting, Organizations and Society, 28(5/6), 507-524

Woodward, J. (1965). Industrial Organization: Theory and Practice. Oxford University Press, London.

Wright, M., \& Stigliani, I. (2012). Entrepreneurship and growth. International Small Business Journal, 31(1), 3-22.

Yukl, G., Gordon, A., \& Taber, T. (2002). A Hierarchical Taxonomy of Leadership Behavior: Integrating a Half Century of Behavior Research. Journal of Leadership and Organizational Studies, 9(1), Summer, 15-32.

Zampiccoli, L. (2009). Le développement des pratiques de contrôle de gestion au sein des collectivités territoriales. Réseau d'Enseignants Chercheurs et Experts en Management Public, 2-10. 


\section{Notes}

Note 1. These practices are presented in the book of Antony (1988)

Note 2. The locus of external control characterizes individuals who consider that what happens in their life is largely determined by a sort of fate or chance, whereas those with an internal locus control consider themselves as masters of their future.

Note 3. A global contingency fit index is calculated for both types of strategy in order to estimate the influence on the performance of the concordance between the strategy, the organizational variables and the control system. The sample is divided into two groups of firms: those with good performance and those with poor performance. An ideal model is then established for firms with good performance and the contingency index is calculated for this model. The correspondence index Contingent is then calculated for the model representing the global data and then compared with the contingency index of the ideal model.

Note 4. Reliance on Accounting Performance Measures (Use of Performance Accounting Measures)

Note 5. A vision that was built by the founding fathers of organizational science (the authors of the scientific management doctrine Taylor and Fayol).

Note 6. In his 1988 book, he introduced a major innovation in relation to his 1965 book.

Note 7. See Appendix 3

Note 8. Teaching: technical (29.7\%), general and technical (42.2\%). Source: our surveys.

Note 9. This explains the non-existence until the end of the 70s of typologies allowing to operationalize the variable "strategy" as a contingent variable.

\section{Appendices}

Appendix 1. Characteristics of the MCS of SMEs in the Sample

Characteristics Number of \%

employees

\begin{tabular}{llll}
\hline $\begin{array}{l}\text { Formalization of the management } \\
\text { control system }\end{array}$ & MC formal system & 194 & 83.6 \\
& MC informal system & 38 & 16.4 \\
\hline Exercice du contrôle de gestion & Centralized MC & 114 & 49.1 \\
& Decentralized MC & 118 & 50.9 \\
\hline Instrumentation of the management & General Accounting & 164 & 70.7 \\
control & Analytical Accounting & 89 & 38.4 \\
& Reporting & 78 & 33.6 \\
& Budget & 101 & 43.5 \\
& planningDashboard & 56 & 24.1 \\
& TBP & 163 & 70.3 \\
& Benchmarking & 146 & 62.9 \\
& Total Quality & 143 & 61.6 \\
& MBA/ABM & 48 & 20.7 \\
& Target costing & 87 & 37.5 \\
\hline Controlling actors & Management owner & 80 & 34.5 \\
& Employee officer & 49 & 21.1 \\
& & 41 & 17.7 \\
& Internal accountant & 47 & 20.3 \\
& External accountant & 15 & 6.5 \\
\hline
\end{tabular}


Appendix 2. Synthesis of the PCA measurementscale after the purification of measurement scales

\begin{tabular}{|c|c|c|c|}
\hline Dimensions & Items & $\begin{array}{l}\text { Number } \\
\text { of items }\end{array}$ & $\begin{array}{c}\text { Cronbach } \\
\text { Alpha }\end{array}$ \\
\hline Complexity & $\begin{array}{l}\text { Quantitative complexity (FAC1_1), Qualitative } \\
\text { complexity }\left(F A C 2 \_1\right) \text {. }\end{array}$ & 9 & 0,745 \\
\hline Variability & Turbulence(FAC1_2), Dynamism (FAC2_2) & 10 & 0,751 \\
\hline Strategy & Strategy(FAC1_3) & 8 & 0,891 \\
\hline Leadership & $\begin{array}{l}\text { Visionary of change (FAC1_4), Development and trust } \\
\left(F A C 2 \_4\right) \text {. }\end{array}$ & 8 & 0,897 \\
\hline $\begin{array}{l}\text { Management } \\
\text { Control } \\
\text { tools }\end{array}$ & $\begin{array}{l}\text { Traditional tools(FAC1_5);Contemporary tools } \\
\text { (FAC2_5). }\end{array}$ & 5 & 0,704 \\
\hline
\end{tabular}

Appendix 3. Analysis of assumptions regression tests

H1: Related variables Complexity / MC traditional tools/Variability/MC formal system

Summary of Models

\begin{tabular}{|c|c|c|c|c|c|c|c|c|c|}
\hline \multirow[t]{2}{*}{ Model } & \multirow[t]{2}{*}{$\mathrm{R}$} & \multirow[t]{2}{*}{ R-two } & \multirow[t]{2}{*}{ R-twoadjusted } & \multirow{2}{*}{$\begin{array}{l}\text { Estimation'sr } \\
\text { esidue }\end{array}$} & \multicolumn{5}{|c|}{ Changes in statistics } \\
\hline & & & & & $\begin{array}{l}\text { Variation } \\
\text { of R-two }\end{array}$ & $\begin{array}{l}\text { Variation } \\
\text { of F }\end{array}$ & dd11 & dd 12 & $\begin{array}{l}\text { Sig. } \\
\text { Variation ofF }\end{array}$ \\
\hline 1 &, $516^{\mathrm{a}}$ & ,266 & ,262 & ,867 & ,266 & 64,858 & 2 & 229 &, 000 \\
\hline
\end{tabular}

a. Predicted values : (constant), Quantitative complexity, Qualitative complexity

ANOVA $^{\text {ba }}$

\begin{tabular}{llllllll}
\hline Model & & Sum of Squares & ddl & $\begin{array}{l}\text { Average } \\
\text { squares }\end{array}$ & of & the D & Sig. \\
\hline \multirow{3}{*}{1} & Regression & 45,412 & 2 & 22,706 & 64,858 &, $000^{\mathrm{b}}$ \\
& Residue & 181,605 & 229 &, 793 & & \\
\hline & Total & 227,017 & 231 & & & \\
\hline
\end{tabular}

a. Predicted value: (constant), Quantitative complexity, Qualitative complexity

b. Dependent value: Traditional tools

\section{Coefficients}

\begin{tabular}{|c|c|c|c|c|c|c|}
\hline \multirow[t]{2}{*}{ Mode } & & \multicolumn{2}{|c|}{$\begin{array}{l}\text { Non standardiz } \\
\text { coefficients }\end{array}$} & \multicolumn{2}{|c|}{$\begin{array}{l}\text { Standardized t } \\
\text { coefficients }\end{array}$} & \multirow[t]{2}{*}{ Sig. } \\
\hline & & $\mathrm{A}$ & Residue & Bêta & & \\
\hline \multirow{3}{*}{1} & (Constant) & $3,575^{\mathrm{e}-17}$ &, 867 & & ,000 & 1,000 \\
\hline & Quantitative complexity & ,427 &, 867 & ,427 & 7,591 &, 000 \\
\hline & Qualitative complexity & ,455 & ,867 & 455 & 8,035 & ,000 \\
\hline
\end{tabular}

a. Dependent value: Management Control tools 


\section{Summary of Models}

\begin{tabular}{|c|c|c|c|c|c|c|c|c|c|}
\hline \multirow[t]{2}{*}{ Model } & \multirow[t]{2}{*}{$\mathrm{R}$} & \multirow[t]{2}{*}{ R-two } & \multirow[t]{2}{*}{ R-twoadjusted } & \multirow{2}{*}{$\begin{array}{l}\text { Estimation'sr } \\
\text { esidue }\end{array}$} & \multicolumn{5}{|c|}{ Changes in statistics } \\
\hline & & & & & $\begin{array}{l}\text { Variation } \\
\text { of R-two }\end{array}$ & $\begin{array}{l}\text { Variation } \\
\text { of F }\end{array}$ & ddl1 & $\mathrm{dd} 12$ & $\begin{array}{l}\text { Sig. } \\
\text { Variation of } \\
\text { F }\end{array}$ \\
\hline 1 &, $658^{\mathrm{a}}$ & ,432 & 429 &, 575 &, 432 & 52,342 & 2 & 191 & 000 \\
\hline
\end{tabular}

a. Predicted Values: (constant), Turbulence, Dynamism

\section{ANOVA $^{\text {ba }}$}

\begin{tabular}{llllllll}
\hline Model & & Sum of Squares & ddl & $\begin{array}{l}\text { Average } \\
\text { squares }\end{array}$ & of & the D & Sig. \\
\hline \multirow{3}{*}{1} & Regression & 25.925 & 2 & 12,625 & 52.342 & $.000^{\mathrm{b}}$ \\
& Residue & 167.075 & 191 & .875 & & \\
\hline & Total & 193.000 & 193 & & & & \\
\hline
\end{tabular}

a. Predicted value: (constant), Turbulence, Dynamism

b. Dependent value :Formal MCS

\section{Coefficients}

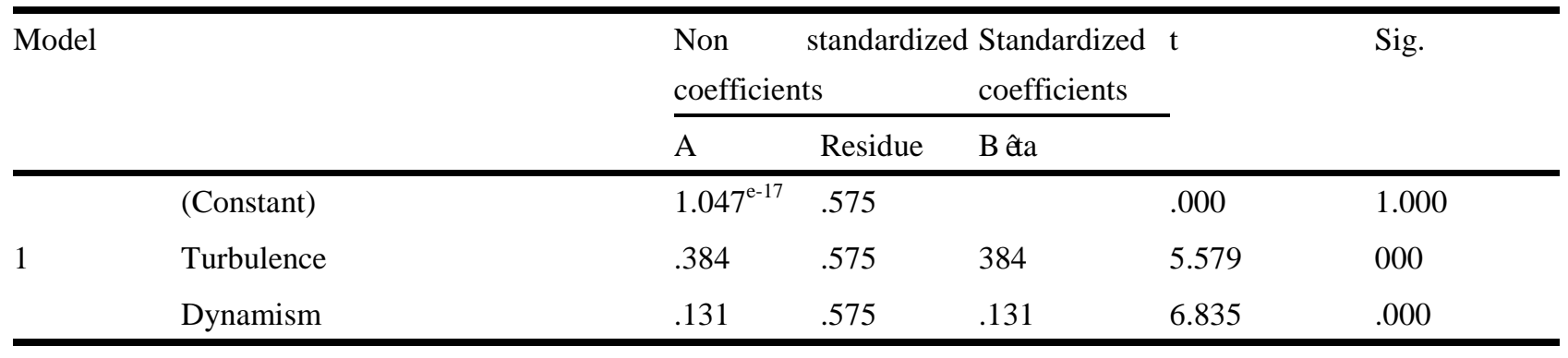

a. Dependent value: Formal MCS

H2: Related variablesStrategy /MCdécentraliséStrategy / Contemporarytools de CG

Summary of Models

\begin{tabular}{|c|c|c|c|c|c|c|c|c|c|}
\hline \multirow[t]{2}{*}{ Model } & \multirow[t]{2}{*}{$\mathrm{R}$} & \multirow[t]{2}{*}{ R-two } & \multirow[t]{2}{*}{ R-twoadjusted } & \multirow{2}{*}{$\begin{array}{l}\text { Estimation } \\
\text { 'sresidue }\end{array}$} & \multicolumn{5}{|c|}{ Changes in statistics } \\
\hline & & & & & $\begin{array}{l}\text { Variation } \\
\text { of R-two }\end{array}$ & $\begin{array}{l}\text { Variation } \\
\mathrm{F}\end{array}$ & of ddll & $\mathrm{dd} 12$ & $\begin{array}{l}\text { Sig. Variation } \\
\text { of } F\end{array}$ \\
\hline 1 &, $768^{\mathrm{a}}$ & ,590 & ,579 & ,750 & ,590 & 62,011 & 1 & 116 & ,000 \\
\hline
\end{tabular}

a. Predicted value: (constant), Strategy 


\section{ANOVA $^{\text {ba }}$}

\begin{tabular}{llllllll}
\hline Model & & Sum of Squares & ddl & $\begin{array}{l}\text { Average } \\
\text { squares }\end{array}$ & of & the D & Sig. \\
\hline \multirow{3}{*}{1} & Regression & 58,925 & 1 & 58,925 & 62,011 &, $000^{\mathrm{b}}$ \\
& Residue & 40,075 & 116 &, 345 & & \\
& Total & 99,000 & 117 & & & & \\
\hline
\end{tabular}

a. Predicted value: (constant), Strategy

b. Dependent values: decentralized MCS

\section{Coefficients}

\begin{tabular}{|c|c|c|c|c|c|c|}
\hline \multirow[t]{2}{*}{ Model } & & \multicolumn{2}{|c|}{$\begin{array}{l}\text { Non standardize } \\
\text { coefficients }\end{array}$} & $\begin{array}{l}\text { Standardized t } \\
\text { coefficients } \\
\end{array}$ & $\mathrm{t}$ & \multirow[t]{2}{*}{ Sig. } \\
\hline & & A & Residue & Bêta & & \\
\hline \multirow{2}{*}{1} & (Constant) & .047 & .750 & & .000 & 1.000 \\
\hline & Strategy & .512 & .750 & .512 & 5.237 & .000 \\
\hline
\end{tabular}

a. Dependent Values : MCS decentralized

Summary of Models

\begin{tabular}{|c|c|c|c|c|c|c|c|c|c|}
\hline \multirow[t]{2}{*}{ Model } & \multirow[t]{2}{*}{$\mathrm{R}$} & \multirow[t]{2}{*}{ R-two } & \multirow[t]{2}{*}{ R-twoadjusted } & \multirow{2}{*}{$\begin{array}{l}\text { Estimation } \\
\text { 'sresidue }\end{array}$} & \multicolumn{5}{|c|}{ Changes in statistics } \\
\hline & & & & & $\begin{array}{l}\text { Variation } \\
\text { of R-two }\end{array}$ & $\begin{array}{l}\text { Variation } \\
\mathrm{F}\end{array}$ & of ddll & $\mathrm{dd} 12$ & $\begin{array}{l}\text { Sig. Variation } \\
\text { of } F\end{array}$ \\
\hline 1 &, $573^{\mathrm{a}}$ &, 328 & ,303 & ,796 &, 328 & 59,178 & 1 & 230 &, 000 \\
\hline
\end{tabular}

a. Predicted value : (constant), Strategy

\begin{tabular}{llllllll}
\multicolumn{7}{c}{ ANOVA $^{\text {ba }}$} & \\
\hline Model & & Sum of Squares & ddl & $\begin{array}{l}\text { Average } \\
\text { squares }\end{array}$ & of & the D & Sig. \\
\hline \multirow{3}{*}{1} & Regression & 128,145 & 1 & 128,145 & 59,178 &, $000^{\text {b }}$ \\
& Residue & 57,091 & 230 &, 248 & & \\
& Total & 185,236 & 231 & & & \\
\hline
\end{tabular}
a. Predicted values: (constant), Strategy
b. Dependent values: Contemporary tools

\section{Coefficients}

\begin{tabular}{|c|c|c|c|c|c|c|}
\hline \multirow[t]{2}{*}{ Model } & & \multicolumn{2}{|c|}{$\begin{array}{l}\text { Non standardiz } \\
\text { coefficients }\end{array}$} & $\begin{array}{l}\text { Standardized } \\
\text { coefficients }\end{array}$ & \multirow[t]{2}{*}{$\mathrm{t}$} & \multirow[t]{2}{*}{ Sig. } \\
\hline & & $\overline{\mathrm{A}}$ & Residue & Bêta & & \\
\hline \multirow{2}{*}{1} & (Constant) & 2,126 & ,796 & & ,000 & 1,000 \\
\hline & Strategy & ,495 & ,796 & ,495 & 7,311 & ,000 \\
\hline
\end{tabular}

a. Dependent value: Contemporary tools

H3 Related variables/Leadership/Contemporary tools/Leadership / MC formal system 


\section{Summary of Models}

\begin{tabular}{lllllllll}
\hline Model & R & R-two R-twoadjusted & $\begin{array}{l}\text { Estimation' } \\
\text { sresidue }\end{array}$ & & & & &
\end{tabular}

a. Predicted values: (constant), Visionary of change; Development and Trust

\section{ANOVA $^{\text {ba }}$}

\begin{tabular}{llllllll}
\hline Model & & Sum of Squares & ddl & $\begin{array}{l}\text { Average } \\
\text { squares }\end{array}$ & of & the D & Sig. \\
\hline \multirow{3}{*}{1} & Regression & 55,484 & 2 & 27,742 & 39,934 &, $000^{\mathrm{b}}$ \\
& Residue & 143,323 & 229 &, 626 & & \\
& Total & 198,777 & 231 & & & \\
\hline
\end{tabular}

a. Predicted value: (constant), Visionary of change; Development and trust

b. Dependent values: Contemporary tools

\section{Coefficients}

\begin{tabular}{|c|c|c|c|c|c|c|}
\hline \multirow{3}{*}{\multicolumn{2}{|c|}{ Model }} & \multirow{3}{*}{$\begin{array}{l}\text { Non } \\
\text { coeffi } \\
\text { A }\end{array}$} & \multicolumn{2}{|c|}{ standardized Standardized } & \multirow[t]{3}{*}{$\mathrm{t}$} & \multirow[t]{3}{*}{ Sig. } \\
\hline & & & & coefficients & & \\
\hline & & & Residue & Bêta & & \\
\hline \multirow{3}{*}{1} & (Constant) &,- 056 & .057 & & -.458 & .041 \\
\hline & Visionary of change & .418 & .059 & .418 & 5.712 & .000 \\
\hline & Development and Trust & .470 & .058 & .470 & 6.650 & .000 \\
\hline
\end{tabular}

a. Dependent value: Contemporary tools

\section{Summary of Models}

\begin{tabular}{|c|c|c|c|c|c|c|c|c|c|}
\hline \multirow[t]{2}{*}{ Model } & \multirow[t]{2}{*}{$\mathrm{R}$} & \multirow{2}{*}{\multicolumn{2}{|c|}{ R-two R-twoadjusted }} & \multirow{2}{*}{$\begin{array}{l}\text { Estimation' } \\
\text { sresidue }\end{array}$} & \multicolumn{5}{|c|}{ Changes in statistics } \\
\hline & & & & & $\begin{array}{l}\text { Variation } \\
\text { of R-two }\end{array}$ & $\begin{array}{l}\text { Variation } \\
\mathrm{F}\end{array}$ & of ddl1 & $\mathrm{dd} 12$ & $\begin{array}{l}\text { Sig. } \\
\text { Variation of } \\
\text { F }\end{array}$ \\
\hline 1 & $.632^{\mathrm{a}}$ & ,399 & .392 & .780 & .399 & 59.087 & 2 & 229 & .000 \\
\hline
\end{tabular}

a. Predicted Values: (constant), Visionary of change; Development et trust 


\begin{tabular}{|c|c|c|c|c|c|c|}
\hline \multicolumn{7}{|c|}{ ANOVA $^{\text {ba }}$} \\
\hline Model & & Sum of squares & ddl & Average of squares & $\mathrm{D}$ & Sig. \\
\hline \multirow{3}{*}{1} & Regression & 118.960 & 2 & 59.480 & 39.934 &, $000^{\mathrm{b}}$ \\
\hline & Residue & 112,040 & 229 & ,489 & & \\
\hline & Total & 231.000 & 231 & & & \\
\hline
\end{tabular}

a. Predicted values: (constant), Visionary of change; Development and trust

b. Dependent values: Formal MCS

\section{Coefficients}

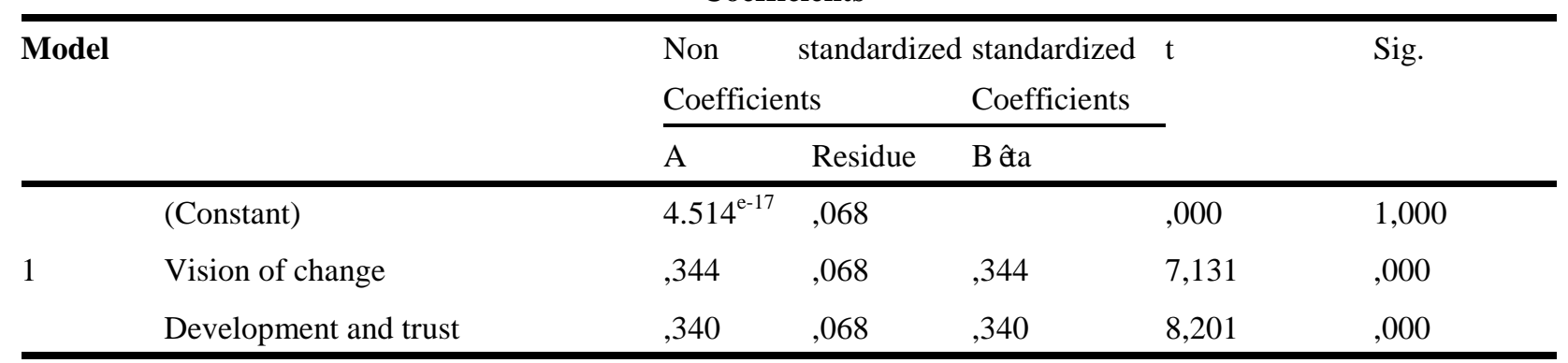

a. Dependent value: formal MCS

Sources: Our results 